\title{
Use of Motivational Strategies in Teaching-Learning Process Among Nurse Educators in Nursing Programmes in Selected States of the South-East, Nigeria
}

\author{
Okonkwo Oluchukwu Ginika', Ogbonnaya Ngozi Phoebe ${ }^{2}$, Anieche John Emenike ${ }^{1}$ \\ ${ }^{1}$ Department of Nursing Science, Nnamdi Azikiwe University, Nnewi, Nigeria \\ ${ }^{2}$ Department of Nursing Sciences, University of Nigeria, Enugu, Nigeria
}

Email address:

og.okonkwo@unizik.edu.ng (O. O. Ginika),ngozi.ogbonnaya@unn.edu.ng (O. N. Phoebe), je.anieche@unizik.edu.ng (A. J. Emenike)

\section{To cite this article:}

Okonkwo Oluchukwu Ginika., Ogbonnaya Ngozi Phoebe., Anieche John Emenike. Use of Motivational Strategies in Teaching-Learning Process Among Nurse Educators in Nursing Programmes in Selected States of the South-East, Nigeria. Journal of Health and Environmental Research. Vol. 7, No. 1, 2021, pp. 23-29. doi: 10.11648/j.jher.20210701.16

Received: December 30, 2020; Accepted: February 14, 2021; Published: February 27, 2021

\begin{abstract}
This is a descriptive cross-sectional study that determined the use of motivational strategies in teachinglearning process among Nurse Educators in nursing programmes in selected states of the Southeast, Nigeria. Population for the study was 112 nurse educators in Schools and Departments of nursing in the Southeast Nigeria. Investigators'developed questionnaire was used for data collection. The instrument was validated for contents and tested for internal consistency through a pilot test and data generated were analyzed using Crombach's Alpha which yielded reliability index of 0.813. Ethical approval from the Research and Ethics Committee of Nnamdi Azikiwe University Teaching Hospital, Anambra State. Data generation was through one-on-one administration of the instrument to the participants. Statistical hypotheses were tested using one-way ANOVA at Confidence Interval of $95 \%$. Study revealed that $97.2 \%$ of the Nurse Educators apply motivational strategies inteaching-learning process out of which $96.1 \%$ indicated "developing lessons that engage students in learning". Majority of them (94.2\%) indicated "establishing an environment that is safe from physical and emotional harm". Study showed that "supporting learning and future goals" were indicated by the Nurse Educators $(\mathrm{x}=3.59, \mathrm{SD}=0.52)$ as a key approach to the application of motivational strategies. Study also revealed that there was no significant difference in the use of motivational strategies between male and female Nurse Educators $\left(t_{(105,025)}=.366, p>.05\right)$. Further still, there is no significant difference in the use of motivational strategies when analyzed according to teaching experience $(\mathrm{F}=1.034, \mathrm{p}>.05)$. The researchers recommend full participation of the Nurse Educators at the point of selection of prospective nursing students to ensure that the best brains with readiness to learn are admitted into nursing programme.
\end{abstract}

Keywords: Motivational Strategies, Teaching, Learning, Nurse Educators, Nursing Programmes

\section{Introduction}

The teaching-learning process is a means through which the teacher, the learner, the curriculum and other variables are organized in a systematic manner to attain predetermined educational goals and objectives [1]. It implies that all the elements of the teaching-learning situations have to be brought into an intelligible whole. Structure of teaching consists of three variables which include; teacher- independent variable, student/learnerdependent variable, content and strategies for presentation- intervening variable [1].

In nursing, learning occurs within a framework of influential factors that affect the character, quality and effectiveness of an educational programme of an institution [2]. In nursing training institutions, the Nurse Educators are the key players in the teaching/learning process. They are the teachers, instructors and guidance-counselors in the teaching/learning activities. They function within the framework of influential factors to ensure proper transfer of knowledge to the prospective nurses in training.

These influential factors include the philosophy of the 
institution, the type of administration, the learner, faculty, types of patients, interests and problems of the community and collective beliefs of those involved in the education programme [2]. The teachers, being the focal figure in education must be competent and knowledgeable in order to impart the knowledge they could give to their students [2]. Nurse educators must be competent, knowledgeable and academically polyvalent to achieve the needed knowledge transfer to the learners entrusted under their care with concern for the student as a person in his general development. The Nurse educator must recognize individual differences among her students and adjust instructions that are best suitable to the learners.

Educators play varied and vital roles in the classroom. They are entrusted with so many responsibilities that range from the very simple to most complex and very challenging job. It is very necessary that they need to understand the need to carry the students along in the classroom. Some students seem naturally enthusiastic about learning, but many need or expect their instructors to inspire, challenge, and stimulate them [3]. Teachers should master the courses they teach in order to encourage effective learning [3]. When students are motivated, then learning would easily take place.

Motivation is a process that arouses channels and gives people's behavior purpose and direction [4]. It is concerned with why people behave the way they do, under certain condition or stimuli [5]. Motivation is of particular interest to educational psychologist because of the crucial role it plays in students' learning domain [6]. Motivation is not something one "does to" others, rather, efforts to motivate students involve first connecting with their interests and their concerns, then broadening these with expanded significant choices, and gradually increasing participants' empowerment to meet these new aspirations [Theall, 2007 in 7]. Motivation is the process of supplying the incentives which will encourage, inspire and influence student to act in a desired behavior to achieve a desired goal [Hanover, 2002 in 4].

\subsection{Literature Review}

Teachers are key actors who shape the learning environment and whose main tasks include motivating students to learn.[8]. Teachers can differ in the way in which they try to motivate students to learn and their motivational strategies can vary from person to person [Hornstra, et al., 2015 in [8].

According to Crookes (1991) in [9], creating motivational condition in the classroom include demonstration of appropriate teacher behaviours, demonstrate the acceptance for and caring behaviour, taking students' learning progress seriously and portray high expectations of what students can achieve. Others include enthusiasm and creation of pleasant and supportive classroom atmosphere, encouraging risktaking and acceptance of mistakes as a normal part of learning.

Furthermore, motivation has been seen as a set of forces that energize, direct, and sustain behavior [10]. These forces can come from the person, so-called "Push" of internal forces, or they can come from the environment that surrounds the person, so-called "pull" of external forces. Motivation thus is to give reason, incentive, enthusiasm, or interest that causes a specific action or certain behavior [Wendy, 2008 in 7]. A learner's motivation is one of the key factors that determine success in learning. Teachers can motivate students by; giving frequent, early, positive feedback that supports students' beliefs that they can do well; ensuring opportunities for students' success by assigning tasks that are neither too easy nor too difficult; helping students' add personal meaning and value in the material; creating an atmosphere that is open and positive; and helping students feel that they are valued members of a learning community [Pyle 2007 in 11].

Pedagogy should at its best be about what teachers do that not only help students to learn but actively strengthens their capacity to learn [12].

Bernaus, et al (2009) [13] identified four categories of motivational strategies; generating initial motivation, rounding off the learning experience, maintaining and protecting motivation, and creating the basic motivational conditions. One of the major importances of motivation is to increase morale of students [Naeem, 2008 in 4]. Motivated students will always think positively and act accordingly in everything they do. It plays a major role in nearly everything the student does. Motivated students tend to work harder, be less stressed, take more care in their studies, be less likely to leave their schools or studies, look for opportunities to improve the processes with which they work and much more [11]. Generally, motivation improves learning [11]. Use of motivational strategies in nursing education can have several effects on students' academic performance. If students are not motivated to learn, they are most likely not involved in the teaching-learning process and if they are not involved, they are more likely to cause classroom management problems [14]. Hence the focus of this study is the use of motivational strategies in teaching-learning process among Nurse Educators in nursing programmes in selected states in the Southeast, Nigeria.

\subsection{Statement of the Problem}

Motivational forces are basic determinants of behavior [14]. Learners must be aroused sufficiently to appreciate the value of education and to work steadily towards the achievement of their goals [1]. It is well known fact that highly motivated students have a lower rate of absenteeism than bordered-motivated students [14]. The major aim of nursing education is to motivate nurses to acquire skills for offering appropriate quality health care services to patients with multiple complex health problems [14].

In recent times, the result chart of some of the training institutions show relative evidence of poor performances in Nursing and Midwifery Council Final qualifying examinations. In almost all the schools of Nursing and Midwifery in the Southeast Nigeria, the researchers observed that during the schools' yearly admission processes, many 
students are selected and admitted into the nursing program but most of these students eventually do not make it to the final year. The number of students that go in for the final qualifying examination is reduced to almost one quarter of the number admitted from inception. The researchers also observed that many students tend to show lack of interest in their academic work hence when they are given assignments such as term papers or any take home work, they tend to copy or reproduce either their friends' or other people's work and submit as their own.

Could these be attributed to the students' inadequate motivation or lack of interest? Or that the nurse educators do not apply appropriate motivational strategies in the teachinglearning process? If they do, to what extent do they apply such motivational strategies? Attempt to answer these questions prompted the researchers' interest to study the use of motivational strategies in teaching-learning process among Nurse Educators in nursing programmes in the Southeast, Nigeria.

\subsection{Objectives}

1) Determine the extent the Nurse Educators use motivational strategies in teaching-learning process in selected nursing institutions.

2) Determine the nurse educators' reasons for applying motivational strategy in teaching-learning process.

\subsection{Hypotheses}

1) $H_{0}$ There will be no significant difference in the use of motivational strategies between male and female nurse educators in nursing programmes in Southeast Nigeria.

2) $\mathrm{H}_{\mathrm{o}}$ Years of teaching experience does not play significant role in the use of motivational strategies among Nurse Educators in nursing programmes in the Southeast Nigeria.

\section{Materials and Methods}

\subsection{Research Design}

This study adopted a descriptive cross-sectional design to investigate use of motivational strategies in the teachinglearning process among Nurse Educators in nursing programmes in selected states in Southeast, Nigeria.

\subsubsection{Area of Study}

The study was carried out in selected states of Southeast, Nigeria. Southeast Nigeria is one of the six (6) geopolitical zones in Nigeria. The randomly selected states for the study include: Anambra, Ebonyi and Enugu States. These states have various nursing schools and departments of nursing including mission and government owned schools which constitute the researchers' study area. Eleven (11) nursing training institutions were used for this study ie; eight (8) Schools of Nursing and three (3) Departments of Nursing Sciences. The Schools of Nursing run three-year progamme in training nurses with only Registered Nursing license while the Departments of Nursing run five-year programme in training Bachelor of Nursing Science graduates. These graduates are nurses licensed to practice as professional nurses by the Nursing and Midwifery Council of Nigeria. It is the responsibility of the Nurse Educators to train these classes of students to be certified as nurses. Training such professionals is tasking and requires motivational strategies to achieve the goal of the programme.

\subsubsection{Population of Study}

Population for the study included nurse educators in these institutions of nursing programmes in Southeast Nigeria. Information from the heads of the training institutions show that a total of one hundred and twelve (112) Nurse Educators teach in these institutions.

\subsection{Inclusion Criteria}

1. Evidence of certification and registration by the Nursing and Midwifery Council of Nigeria as Nurses Educator.

2. Evidence of teaching in nursing training institution for not less than two years.

3. Willingness to participate in the study.

\subsection{Instrument for Data Collection}

Researchers' developed questionnaire structured in close ended format in line with the objectives of the study was the instrument used to generate data for the present study.

The instrument was validated for face and content by experts in Measurement and Evaluation Department of University of Nigeria before being certified valid for data collection.

\subsection{Reliability of the Instrument}

The instrument was pretested for internal consistency through pilot test conducted in one nursing school which was not among the selected institutions for the study. Data generated from the pilot study were analyzed using Cronbach's Alpha which yielded reliability index of 0.813 .

\subsection{Ethical Considerations}

Research and Ethics Committee approval with reference number NAUTH/CS/152/VOL. 2/66 granted the researchers the permission to embark on the study. Consent was obtained from each participant for willingness to participate and there was compliance to confidentiality of privileged information from the participants.

\subsection{Procedure for Data Collection}

Approval from Research and Ethics Committee was presented to the management of the training institutions for permission before compliance was sought from the participants. The purpose of the study was explained to the individual Nurse Educators as they were met in their offices or convenient areas as they requested. The instrument was self-administered by the researchers and on one-on-one basis. Only those that met the inclusion criteria participated in the 
study. Data collection lasted eight (8) weeks.

\subsection{Method of Data Analysis}

Data generated with the instrument were analyzed using descriptive and inferential statistics. Statistical hypotheses were tested using one-way analysis of variance (ANOVA) at Confidence Interval (CI) of $95 \%$.

\section{Results}

Table 1. Demographic variables of the respondents $n=107$.

\begin{tabular}{|c|c|c|c|c|}
\hline Demographic variable & Category & Freq. & $\%$ & Remark \\
\hline \multirow{6}{*}{ Age } & $25-30$ & 11 & 10.3 & \multirow{6}{*}{ * } \\
\hline & $31-36$ & 17 & 15.9 & \\
\hline & $37-42$ & 26 & 24.3 & \\
\hline & $43-48$ & 27 & 25.2 & \\
\hline & $49-54$ & 12 & 11.2 & \\
\hline & 55andabove & 14 & 13.1 & \\
\hline \multirow[t]{2}{*}{ Sex } & Female & 92 & 86.0 & \multirow[t]{2}{*}{$*$} \\
\hline & Male & 15 & 14.0 & \\
\hline \multirow[t]{3}{*}{ Marital status } & Married & 91 & 85.01 & \multirow[t]{3}{*}{ * } \\
\hline & Single & 14 & 13.08 & \\
\hline & Widowed & 2 & 1.9 & \\
\hline \multirow[t]{3}{*}{ Employment } & Fulltime & 96 & 89.7 & \multirow[t]{3}{*}{ * } \\
\hline & Part time & 4 & 3.7 & \\
\hline & Contract & 7 & 6.5 & \\
\hline \multirow[t]{5}{*}{ Experience (years) } & $<1$ & 6 & 5.6 & \multirow{5}{*}{ * } \\
\hline & $1-9$ & 49 & 45.8 & \\
\hline & $10-19$ & 34 & 31.8 & \\
\hline & $20-29$ & 6 & 5.6 & \\
\hline & $\geq 30$ & 12 & 11.2 & \\
\hline \multirow[t]{5}{*}{ Qualification } & $\mathrm{RN}$ & 1 & 1.0 & \multirow{5}{*}{ * } \\
\hline & $\mathrm{RN} / \mathrm{RM}$ & 7 & 6.5 & \\
\hline & B. Sc & 49 & 45.79 & \\
\hline & M. Sc & 41 & 38.32 & \\
\hline & Ph. D & 9 & 8.4 & \\
\hline
\end{tabular}

Mean Age $=43.00, \mathrm{SD}=9.21$

Table 2. Nurse Educators' use of motivational strategies in teaching-learning process.

\begin{tabular}{|c|c|c|c|c|c|}
\hline SN & Use of motivational strategies in teaching-learning process & Yes & $\%$ & No & $\%$ \\
\hline 1 & Do you apply motivational strategies in your teaching-learning process? & 104 & 97.2 & 3 & 2.8 \\
\hline $2 \mathrm{a}$ & $\begin{array}{l}\text { If yes, which of these motivational strategies do you usually apply while teaching? } \\
\text { Focus on learning instead of performance }\end{array}$ & 67 & 64.4 & 37 & 35.6 \\
\hline B & View grades as an indicator of learning & 45 & 43.3 & 59 & 56.7 \\
\hline $\mathrm{C}$ & Develop lessons that engage students in learning & 100 & 96.1 & 4 & 3.9 \\
\hline $\mathrm{D}$ & Use classroom and content to help set and attain proximal and distal goals & 88 & 84.6 & 16 & 15.4 \\
\hline E & Begin with student interest and talents on an academic, personal and social level & 84 & 80.8 & 20 & 19.2 \\
\hline $\mathrm{F}$ & Relate educational processes and products to students' past and future & 74 & 71.2 & 30 & 28.8 \\
\hline G & Tailor the relevance to individual students' interests & 72 & 69.2 & 32 & 30.8 \\
\hline $\mathrm{H}$ & Offer students choices that allow them to connect the classroom with their own talents and interests & 80 & 76.9 & 24 & 23.1 \\
\hline I & Establish an environment that is safe from physical and emotional harm. & 98 & 94.2 & 6 & 5.8 \\
\hline $\mathrm{J}$ & Build an atmosphere where mistakes are included as part of the learning process & 82 & 78.8 & 22 & 21.2 \\
\hline $\mathrm{K}$ & Know each student as a person and not just as part of the classroom & 89 & 85.6 & 15 & 14.4 \\
\hline $\mathrm{L}$ & Provide students with ample opportunities for success & 95 & 91.3 & 9 & 8.7 \\
\hline M & Connect student accomplishments to task value & 64 & 61.5 & 40 & 38.5 \\
\hline $\mathrm{N}$ & Set high and achievable standards of excellence & 84 & 80.8 & 20 & 19.2 \\
\hline \multirow[t]{5}{*}{3} & $\begin{array}{l}\text { At what period of the teaching process do you apply the identified motivational strategies? (Tick as many as } \\
\text { applied to you). }\end{array}$ & Freq & $\%$ & & \\
\hline & Beginning of lecture & 47 & 45.2 & & \\
\hline & In the middle of lecture & 36 & 34.62 & & \\
\hline & Ending of lecture & 25 & 24.0 & & \\
\hline & All of the above & 83 & 79.81 & & \\
\hline
\end{tabular}


Table 3. Nurse Educators' reasons for applying these motivational strategies in teaching-learning process frequency of application.

\begin{tabular}{|c|c|c|c|c|c|}
\hline $\mathbf{S N}$ & $\begin{array}{l}\text { Indicate why you apply these motivational strategies in teaching-learning } \\
\text { process }\end{array}$ & Always (4) & Occasionally (3) & $\begin{array}{l}\text { Rarely } \\
(2)\end{array}$ & Not at all (1) \\
\hline A & To support learning and future goals & 62 & 41 & 1 & 0 \\
\hline B & To establish relevance and connecting to students' interest & 57 & 41 & 6 & 0 \\
\hline $\mathrm{C}$ & To treat students as uniquely valued individuals & 71 & 27 & 4 & 2 \\
\hline $\mathrm{D}$ & To foster student valuing and perceived competence & 50 & 43 & 9 & 2 \\
\hline
\end{tabular}

Table 3. Continued.

\begin{tabular}{|c|c|c|c|c|c|}
\hline \multirow[b]{2}{*}{ SN } & \multirow[b]{2}{*}{ Indicate why you apply these motivational strategies in teaching-learning process } & \multirow[b]{2}{*}{ Mean } & \multicolumn{3}{|c|}{$95 \% \mathrm{CI}$} \\
\hline & & & SD & LB & UB \\
\hline A & To support learning and future goals & 3.59 & 0.51 & 3.49 & 3.69 \\
\hline B & To establish relevance and connecting to students' interest & 3.49 & 0.59 & 3.39 & 3.62 \\
\hline $\mathrm{C}$ & To treat students as uniquely valued individuals & 3.61 & 0.7 & 3.44 & 3.72 \\
\hline \multirow[t]{2}{*}{$\mathrm{D}$} & To foster student valuing and perceived competence & 3.36 & 0.69 & 3.24 & 3.51 \\
\hline & Grand mean and SD & 3.45 & 0.62 & 3.33 & 3.57 \\
\hline
\end{tabular}

Table 4. Summary of independent sample t-test on the difference in the use of motivational strategies between male and female teachers.

\begin{tabular}{llllllll}
\hline Gender & N & Mean & SD & SEM & T & Df & p-value \\
\hline Female & 92 & 2.29 & 0.23 & 0.02 & .366 & 105 & .715 \\
Male & 15 & 2.27 & 0.14 & 0.04 & & & Decision \\
\hline
\end{tabular}

Table 5. Summary of one-way Analysis of variance on the difference in the use of motivational strategies when analyzed according to years of teaching experience of the Nurse Educators.

\begin{tabular}{|c|c|c|c|c|c|c|c|c|}
\hline \multirow{2}{*}{$\begin{array}{l}\text { Years of teaching } \\
\text { experience }\end{array}$} & \multirow{2}{*}{$\mathbf{N}$} & \multirow{2}{*}{ Mean } & \multirow{2}{*}{ SD } & \multicolumn{5}{|c|}{$95 \%$ CI } \\
\hline & & & & LB & UB & $\mathbf{F}$ & Sig. & Decision \\
\hline$<1$ & 6 & 2.24 & 0.37 & 1.85 & 2.62 & 1.034 & .394 & Not sig. \\
\hline $1-9$ & 47 & 2.28 & 0.18 & 2.23 & 2.33 & & & \\
\hline $10-19$ & 34 & 2.28 & 0.20 & 2.21 & 2.35 & & & \\
\hline $20-29$ & 7 & 2.24 & 0.18 & 2.04 & 2.43 & & & \\
\hline$\geq 30$ & 13 & 2.40 & 0.36 & 2.17 & 2.63 & & & \\
\hline
\end{tabular}

\section{Discussion}

\subsection{Extent of Use of Motivational Strategies in Teaching-Learning Process Among the Nurse Educators}

From the study, it was deduced that $97.2 \%$ of the nurse educators apply motivational strategies in teaching-learning process out of which $96.1 \%$ indicated "developing lessons that engage students in learning". Majority of them (94.2\%) indicated "establishing an environment that is safe from physical and emotional harm". Substantial number of the nurse educators $(56.7 \%)$ does not view grades as indicator for learning. This implies that learning is said to occur when the learner, the teacher, the environment and the curriculum are in agreement. Grades are not good indicator that learning has taken place because some students might be involved in examination malpractices in order to achieve the grades they hope for even when they do not attend classes.

Majority of the nurse educators (79.81\%) indicated that they apply motivational strategies at the beginning, in the middle and at the ending of their lectures. This agrees with the findings of $[15,7]$. Study also revealed that "supporting learning and future goals" $(\mathrm{x}=3.59, \mathrm{SD}=0.52)$ was indicated by the Nurse Educators as a key approach to the application of motivational strategies with $95 \%$ confidence interval moving from 3.49 to 3.69. "Treating students as uniquely valued individuals" had a mean score of $3.58, \mathrm{SD}=0.70$ while the least was "fostering student valuing and perceived competence" ( $x=3.36, \mathrm{SD}=0.69)$. This result agreed with [13] which suggest that teacher motivation is related to teacher use of motivating strategies, which in turn are related to student motivation. The result also rhymes with the findings of [15] where teachers were observed and were categorized as "high" implementers and "low" implementers depending on the fidelity with which they delivered the intervention.

\subsection{Nurse Educators' Reasons for Applying Motivational Strategies in Teaching-Learning Process}

Nurse educators' reasons for applying motivational strategies in their teaching/learning process are divers and include: to support learning and future goals, establish relevance and connecting to students' interest, treat students as uniquely valued individuals and foster student valuing and perception with grand mean $3.45, \mathrm{SD} \pm 0.62$. This is in line with the findings of [16], where usage of effectual teaching methodologies, adequate learning environment in the classroom, self-motivated involvement of the students, large class size etc were the foremost determinants that can increase the students motivation for learning process.

\subsection{Difference in the Use of Motivational Strategies Between Male and Female Teachers}

Result showed no significant difference in the use of 
motivational strategies between male and female Nurse Educators $\left(\mathrm{t}_{(105,025)}=.366, \mathrm{p}>.05\right)$. The null hypothesis was accepted. This implies that both male and female teachers make adequate use of these motivational strategies while teaching. None uses them more than the other $2.29, \mathrm{SD}=0.23$ and the mean score of the male teachers was $2.27, \mathrm{SD}=0.14$.

\subsection{Influence of Years of Teaching Experience on the Use of Motivational Strategies Among the Nurse Educators}

Results showed no significant difference in the use of motivational strategies when analyzed according to teaching experience $(\mathrm{F}=1.034, \mathrm{p}>.05)$. This could be as a result of the knowledge of these motivational strategies the teachers have which have led to their use during teaching. This is in line with the saying "one cannot give what one doesn't have". This finding is in agreement with the study by [7] that primary school teachers widely use confidence-building motivational strategies in their teaching of mathematics. [13] Had the same view that teachers' motivation is related to teacher use of motivating strategies, which in turn are related to student motivation.

\section{Conclusion}

The study revealed that the nurse educators apply motivational strategies in teaching-learning process as means of providing emotional support to the students and treating the students as uniquely valued individuals. This will provide great support to the student nurses' interest and value for academic pursuit. Teaching experience and gender will not be seen as barriers in the application of motivational strategies in teaching-learning process to potentiate expectations from the nurse educators.

The need for nurse educators and other teachers to be conversant with motivational strategies and the application modality should not be overemphasized because the outcome in teaching learning is golden.

\section{Implications of the Study}

Nurse educators are challenged on how to best equip nursing students to care for patients in an increasingly complex healthcare environment. This challenge is exacerbated by the shortage of nurse educators, increasing severity of patient illnesses, and rapid technological changes in the healthcare setting. Since the nurse educators implement motivational strategies in their teaching/learning process, the need for total students' participation remains an issue to be dealt with to achieve the best in the students with improved academic performance. Active teaching-learning motivational strategies require that students put forth time and effort towards learning, and places students at the centre of learning. Classroom activities need to focus on actively building students' knowledge rather than allowing them to be passive recipients of information.

\section{Recommendations}

The researchers recommend full participation of the Nurse Educators at the point of admission to ensure that the best brains and with interest to learn are admitted into nursing programme to ensure that the Nurse Educators' input in the teaching/learning process yields expected outcome.

Parents should be directly or indirectly involved in removing the educational constraints of their children. Students need guidance and motivation in order to enhance their educational performance and parents can play great role in this aspect to compliment the actions of the nurse educators. Parents should allow their children to go for courses on career choice and allow them to go in for their preferred career choices in the higher institution rather than deciding their fate for them.

\section{Limitations of the Study}

This is a descriptive study and the researchers cannot wholly ascertain the nurse educators' applicability of the motivational strategies in the teaching/learning process and correlate it to the performance of the students in the study area which factored this study.

The fact that years of teaching experience does not play a significant role in their use of motivational strategies draws attention that tends to question the popular saying that older practitioners tend to have more experience than the younger ones. This therefore becomes another source of concern as observation of the nurse educators in their course of teaching/learning activities was not done in the course of this study.

\section{Conflict of Interest Statement}

The authors declare that they have no competing interests.

\section{Acknowledgements}

We acknowledge the Nurse Educators in nursing programmes in the selected states of the Southeast, Nigeria for their time and efforts in making this study a reality.

\section{References}

[1] Basavanthappa, B. T. (2009). Nursing Administration. Jaypee Brothers Medical Publisher Ltd.

[2] Barbarous, M., Gozalo, A. and Padayogdog, E. (2013). The Effect of teachers Teaching Style on Students' Motivation. Action Research. LeeTzongjin, Ed).

[3] Hardell, T. L. (2011). Motivating Nursing faculty to use Active learning strategies: A Qualitative multiple case study. (Doctoral dissertation). Retrieved from proQuest LLC (Umi Dissertation Publishing 3528761.

[4] Magda, A. G., \& Manal, S. M. (2015). Development of Motivational strategies for nursing students at Zagazig University in Egypt. Journal of Nursing Education and practice. http://dx.org/10.5430/jnep.v5n6p62. 
[5] Okoronkwo, I. (2005). Nursing Service, Administration and Management: Theory and Practice. Institute for Development Studies Publishers.

[6] Cassandra, R. (2005). Moving critical thinking to the main stage. Education Canada, 45 (2), 45-49.

[7] Rudhumbu, N. (2014). Motivational strategies in the teaching of primary School mathematics in Zimbabwe International Journal of Education Learning and Development UK vol. 2 No 2, PP. 76-103.

[8] Arul-Lawrence, A. S. and Hanitha, T. (2017). A Study on Teachers' Motivational Strategy and Academic Achievement of Higher Secondary Students. School of Education, Tamil Nadu Open University, Chennai, India. Aarhat Multidisciplinary International Education Research Journal.

[9] Kirondo, Y. A. (2014). Strategies Employed by Teachers to Motivate Students in Kinondoni municipality (Dissertation). Open university of Tanzania.

[10] Hit, Black \& Porter, (2005). Management. (2 ${ }^{\text {nd }}$ Ed). Texas: University Pearson publisher.

[11] Manktel, (2007). Manage Stress: Take back Control in your life. University of Waleer hompton UK: Psychology Press.
[12] Taylor, L. \& Parsons, J. (2011). Improving Student Engagement, Current Issues in Education, 14 (1). Retrieved from http://cie.asu.edu/.

[13] Bernaus, M., Wilsom-Daily \& Gardner, R. (2009). Teacher's motivation, classroom strategy use, students' motivation and second language achievement. University of western Ontario. Porta linguarium. https://www.google.com.

[14] Hanifi, N., Parvizy, S., \& Joolace, S. (2012). Nursing Challenges in motivating Nursing Students through Clinical education: A grounded Theory Study. Nursing research and practice. http://dx.doi.org/10.1155/2012/161359.

[15] Miller and Meece (2007). Predicting the Academic Motivation of Rural High School Students. Department of Educational Psychology, University of Oklahoma. The Journal of Experimental Education Vol. 75 No 4 pp. 247-269. Published by Taylor \& Francis Ltd.

[16] Ullah, M. I., Sagheer, A., Sattar, T., \& Khan, S. (2013). Factors Influencing Students Motivation to Learn in Bahauddin Zakariya University, Multan (Pakistan). International Journal of Human Resource Studies, 3 (2), 90. 